\title{
NORTH KOREAN STRATEGIC CULTURE: SURVIVAL AND SECURITY
}

\author{
Lucia HUSENICOVA \\ lucia.husenicova@gmail.com \\ MATEJ BEL UNIVERSITY IN BANSKA BYSTRICA, SLOVAKIA
}

\begin{abstract}
During last year North Korea has made almost daily headline. Topics such as the strongest nuclear test, tests of missiles from medium range ballistic missiles (MRBM) to intercontinental ballistic missiles (ICBM), readiness to retaliate to any possible U.S. attack, appeared frequently. In addition, the reaction of U.S. president D. Trump about American readiness to solve the issue, sending armada or reacting with fire and fury, were also covered by media all around the world. With these developments a possibility of nuclear war was discussed for the first time since the end of Cold War.

This article aims to look closer to the reasons of North Korean behaviour, not only in last few years but within the contest of the concept of strategic culture. This concept has been used to explain behaviour of powers mainly, but the article aims to prove it is a viable tool to explain the motives and perceptions of any state in international system. The article aspires to conclude that the North Korean foreign and security policy is necessary to perceive in more complex picture. The current situation in North Korea is a result of combination of several factors that are determining and that have formed its perception of international relations.
\end{abstract}

\section{KEYWORDS:}

North Korea, nuclear program, strategic culture, security, military

\section{Strategic culture as a concept}

The main purpose of the concept of strategic culture was to explain different perceptions of reality and patterns of behaviour of the U.S. and USSR during the Cold War period. The concept as such is a combination of the impacts of cultural background of the country and strategic behaviour the country applies in its security and foreign policy, however there are features of both that play different roles under different circumstances. Through the evolution of the concept, different definitions and perceptions of its influence have been offered. Currently, we are talking about three different generations of research within the strategic culture concept (Johnston, 1995). They vary quite significantly, from perceiving the culture as being deterministic for behaviour of a state, through attempts to select periods and trends of development that are most influential for a country and political representatives who might have manipulated masses and their own successors, to the perception that the political-military culture depends and 
changes as the domestic politics does. All these developmental stages have contributed to the evolution of the concept as such, they have shown the weaknesses and strengths of it vis-à-vis other theoretical approaches. We can say, that concerning the concept of strategic culture, there is no unified or shared perceptions of the concept. This is not an exception in the research on IR, what it suggests is, that this concept is still under development. Its potential and influence on theoretical discourse is yet to be seen.

In an attempt to define the concept, to offer an understanding of what the potential application can bring to the research, we need to define what we perceive under culture. Consequently, we can present definition of the whole concept, under current circumstances in social science and based on the mentioned three branches the definitions that exists are multiple and different, we will look at those most significant.

There are multiple definitions of culture in social science, however we will be looking at those that have been stressed within the research of strategic culture. Alastair Johnston, one of the representatives of scholars of strategic culture uses multiple definitions of culture which can be summarized as "collectively held semiconscious or unconscious images, assumptions, codes, and scripts which define the external environment' (Johnston, 1995, p. 44). In more detail, these images, codes, assumptions form the perceptions the people who share them have about their realities within the society and also their relations to others. What is important is that within anthropology the culture is defined not only ideationally but also through a rituals that people conduct. However, the culture does not explicitly explain behaviour of people, but provides information about the overall societal orientations and sets an agenda for behaviour.

Furthermore, in connection to the concept of strategic culture the term political culture is also used as a second step in defining the whole concept. Political culture has "anthropological as well as historical origins" (Lantis, 2002, p. 91), the first group consists of language, religion, customs or habits and processes of socialization, while the second represents the shared experiences of the group or the shared interpretations of historical events. In a more narrow sense the political culture influences the perceptions of political institutions by the people, in a way it defines their mind-set that tends to limit the spectrum of options available in specific situation when a decision needs to be taken.

As mentioned above the concept of strategic culture was elaborated during the Cold War, more specifically in the late 1970 s by political scientist Jack Snyder who defines it in most broad meaning as "sum-total of ideas, conditioned emotional responses and patterns of habitual behaviour that members of national strategic community have acquired through instructions or imitations" (Snyder, 1977, p. 8). Based on Snyder's definition the way political elites perceive security issues and threats is influenced by the knowledge they have acquired in what he calls process of socialization that is strongly influenced by the interpretation of historical experiences of people/nation. What is important to emphasize is that Snyder considers the strategic culture to be change-prone due to ongoing development. He especially stresses the impact of technological change on different doctrines connected to the concept, primarily to nuclear weapons and nuclear doctrines.

Elaborated further, the concept as such was perceived in broader as well as more narrow perspectives. The broader definition was offered by Ken Booth who defined the strategic culture as "nation's traditions, values, attitudes, patterns of behaviour, habits, symbols, achievements and particular ways of adapting to environment and solving problems" (Booth, 1990, p. 121) related to use of force. $\mathrm{He}$ adds that the strategic culture is rooted in a history of nation, geography as well as 
political culture and these are often presented by political elite of specific nation. The concept as such is defining the position of nation towards war and peace and in this way the relations with others.

An example of the more elaborated definition is one provided by A. Johnston defines strategic culture as "an integrated system of symbols which acts to establish pervasive and long lasting strategic preferences by formulating concepts of the role and efficacy of military force in interstate political affairs, and by clothing these conceptions with such an aura of factuality that the strategic preferences seen uniquely realistic and efficacious" (Johnston, 1995, p. 46). There are two main features of the strategic culture. The first one is a general assumptions about the strategic environment, the role of war, knowledge on the potential enemy and position on the usage of force. The second feature is operational in nature, based on the selection of the most efficient strategy based on the assessment of the issues related to the first mentioned feature (Johnston, 1995). Basically, one of the main features of strategic culture is the perception of a specific community on the use of force in their foreign policy. Naturally, these perceptions are subject to a change, or transformation depending on the overall situation in external environment and also on the situation within the community, be it a sovereign state or group of states within a region. The problem is, that in order to encompass the overall strategic culture and its influence, the knowledge of history and identification of most influential events in community's development need to be analysed first.

However, what is a most complicated part of formulation of the concept and its practical influence is the relation between theoretical definition of the concept and a real behaviour of community. The issue of determinism is the one most questioned. This is related to the question of change in strategic culture as historically we have to admit that some communities with a violent past are peaceful in present time and the other way around. As Johnston suggests the strategic culture is strongly related with a preferences of a community. These can be changed based on the current analysis and assessment of questions related to the above mentioned features of the concept.

To summarize, concept of strategic culture can be helpful in an effort to explain why states or communities tend to react differently in the same situations. Even if objective assessment of external environment is similar, the final strategy depends at the end, not only on perceptions of reality but also on the particular historical experiences of that specific community. In addition, traditions and values inherent to the community often shape these perceptions of reality.

\section{Features of strategic culture}

In order to use the concept as an analytical tool we need to define features of strategic culture that can be observed in our selected case of North Korea. Within the years of development of the concept discussions have been taking place about what all features need to be encompassed to bring a desirable results of the analysis that would point out the differences among strategic cultures of different states, nations and peoples. As suggested by the definitions of strategic culture, some analysist focus mainly on its military aspects related to war and approach of the people to use of force, some approach it more broadly through the overall approach to the politically related aspects of nation's life.

The features we will use can be divided into two categories, first are those that are not changeable and second are those undergoing change or transformation over time. In addition, the other categorization that we can use is dividing the features to material and ideational. Regarding the specific features or sources as they are called by D. Howlett we will use the following: "geography, climate and 
resources; history and experience; political structure; the nature of organizations involved in defense; myths and symbols; key texts that inform actors of appropriate strategic action; and transnational norms, generational change and the role of technology" (Howlett, 2005, p. 5). Although their specific understanding is mainly of our own.

In order to divide them based on our two primary categories, those who are not change-prone will be: geography, history and experience and myths and symbols. Nevertheless in the last two features it is necessary to emphasize that their interpretation could be altered over the time of development of the society. Especially, in the case of myths and symbols North Korea is an interesting and proving example of how perceptions and understandings can change. The remaining features are prone to change or transformation or further evolution, depending on specific development of society.

Using the second suggested categorization, material features will be those who can be measured or predicted or are physically influencing the realities of specific society. Therefore in this category we include geography, climate and resources, key text informing actors about strategies, role of technology, transnational norms, political structures and nature of organization of defense institutions. The ideational features are following: myths and symbols, generational change in this case perceived mainly through education and interpretation of history and experiences.

Naturally, as obvious from both categorization some features' character is disputable as they could be part of both or they can form a specific category of variables. A brief characterization of each will provide us with clearer affiliation of specific feature.

First from among material features the geography can be connected with climate and resources, even though they are not necessarily interdependent. The influence of geography on the policy of state is thoroughly studied by the geopolitics and in this case related to the physical features of territory which either provide natural borders between states or not. Geography is considered important also due to a proximity of powerful neighbors, or the amount of neighbors and character of mutual relations. In this case U.S. are specific example as opinions exist claiming the position of U.S. in international system is facilitated by their position and by lack of imminent threat in their neighborhood. This can be given into contrast with Russia, country with the biggest number of neighbors, some presenting significant challenge to its security. Looking at climate, the ongoing changes play still bigger role for every country, as climate is impossible to control. Its changes significantly influence situation in countries not only internal and economic but also external defined by relation of country towards different campaigns fighting the climate changes. Here China is an interesting case, a country that is undergoing most radical change in production that causes significant climate problems. The methods for change have been supported even urged by the population and government itself and now China is becoming one of the greatest investors into a green technologies and renewable energies. The last in this group are resources in form of natural resources that can strongly shape foreign policy of a country, as the case of U.S. showed in the past when also a perception of the use of force in the situation of securing access to these is different to an overall use of force. In addition, possession of resources gives a country certain options vis-à-vis others.

Second feature are texts or documents encompassing recommended strategies for action. These documents are adopted regularly by governments of most of the countries, they in general state the aims of foreign and security policy and provide for specific descriptions of strategies that are to be applied in order to achieve goals. 
Specific documents are those setting the grand strategies and the nuclear doctrines of nuclear states. Nevertheless the documents usually are influenced by the other features of strategic culture and therefore it is disputable whether we should consider them as part of its definition.

Third material feature is the technology and its role in strategic culture, in this relation what is mainly considered is the state of military technology, development and types of weapons the country has to its disposal. This feature represents the one rooted in original perception of the concept of strategic culture in the period of Cold War's nuclear race. Nevertheless, the advancement of technology also suggests position of people towards the use of force. If a significant money is spend on modernization it is influenced by the threat perception of the population and politicians that could be caused by the geographic location, proximity of competing state, terrorist organization, etc.

Fourth feature is presented by transnational norms that aim to regulate the conduct of international relations. The U.N. and documents adopted on the level of U.N. will be a first level of regulation, the other level is formed by documents regulating relations on regional level, and lastly the bilateral agreements.

The father feature, the political structure is significantly connected to the character of political system and the division of power in general and more particular the division of competencies among specific state agencies participating on foreign and security policy. As a practice has proven there are specific procedures adopted by countries that are liberal democracies in the internal operationalization of institutions as procedures of decision making, problems and disputes solving, etc. Moreover, the liberal democracies and their population are generally against conflicts or war and prefer peaceful and diplomatic solutions. However, this statement does not apply generally and there are exceptions. When looking at authoritarian or totalitarian regimes the process of decision making usually depends on one leader or limited group of persons who are not limited by different institutions as the division of power generally does not work in these countries.

Last feature, related to the previous is nature of organization of defense institutions, meaning position of military, police, security and intelligence organization. Again there is a difference between democratic and nondemocratic countries especially in the area of influence of these agencies on politics and social realities, their relations to political leadership and control of the leadership over these agencies.

The other category, the one of ideational features of strategic culture represent more the overall background of every country, in a sense of sources of identity of its citizens and their culture. This influences how and why have people certain perceptions about themselves and others. The first feature, as mentioned above, are myths and symbols. These are specific for every group or society, which form nation and some form a national state, some are part of a state with other groups. Myths and symbols go all the way back to explaining how the nation was created, what is the relation of the people to the territory, how did they form a state. As for symbols there are equally important for perceiving and defining own identity. These could be religious, or/and also related to specific historical experience of the particular group of people. The history and experiences are connected to the myths and symbols, as often there is a relation between the most significant historical moments and symbols of a nation or a country. What is important to emphasize here is also the aspect of interpretation of history and experiences of a country. Every state has experienced problems or conflict in relations to others or one of the powers, however the way how these events are narrated influences the perception of historical experience as well as relations to 
others. Therefore the feature of education could be seen as an integrated feature with the two previous. As the understanding of symbols, myths and historical experiences is shared through the educational institutions.

All these features form state's strategic culture. Naturally, as mentioned above their categorization could be discusses, as well as the features themselves. However, as strategic culture is a concept constantly under development changes in features are not only possible but also expected and welcome.

\section{Strategic culture of North Korea}

The following section will look at the application of above mentioned features of strategic culture to a specific case of North Korea, or Democratic People's Republic of Korea (DPRK). The state was created almost 70 years ago, in September 1948 . In this period it has managed to form one of the most unique political systems in human history. The system could be considered totalitarian as it shows features of most definitions of totalitarian regime formulated in West. As it is regular case in social sciences there is not just one definition of totalitarianism. The first one we will use is historically older and was formed by Italian politician Luigi Sturzo who has left for exile after Mussolini took power and has written extensively about totalitarianism. He characterizes totalitarian state as having four features: "(1) an extreme monopoly of the administration, (2) a militarization of society, (3) a state monopoly on education and (4) a subordination of the economy to the state" (Schäfer, 2004, p. 25). All these features can be found in North Korean political system. The public life in North Korea is under constant surveillance as the security agencies and police control population constantly. The society is highly militarized, North Korea has a 10 year lasting compulsory military service that can be voluntarily extended if the person is interested. In addition, the environment of permanent threat is constantly emphasized together with imminent readiness for combat. In DPRK the education system is completely controlled by the state, the content of the classes is strictly prescribed by the state institutions starting in kindergarten ending on university level, however continuing in indoctrination lessons at work. The history of North Korea and the specifics of its political system, official myths and narratives are explained in form of tales at the beginning, later the facts and realities are elaborated (Lankov, 2007). In this regard a sort of religious system is created in North Korea where leaders are presented as a god-like figures. North Korean economy is centrally planned, even though it is going through a program of reforms currently and few features of free market are introduced the decisions of state are still important. Although we have to admit that a strong, grey economy exists in the country that state is trying to get under its control recently (Park, 2013). This grey economy is represented by the farmer's markets which are being recognized by the state.

The other definition of totalitarian regime that provides a helpful insight into North Korean political system is one represented by German theoretician Peter Bernholz. He believes that one of the most significant feature of totalitarian regime is ideology which provides the regime with a specific world view based on specific values. Ideology however is not sufficient to create a totalitarian regime, three other features need to be in place. First is existence of "organization supporting the ideology with leader or leadership with monopoly to interpret it." Second is related to the position of the previously mentioned group which integrates into its hands "spiritual and secular leadership". Third feature is critical situation the society appears in and the previous two can be realized (Bernholz, 2007, p. 248). When looking at North Korean political system applying this definition we see how big influence state ideology juche plays in functioning of institutions, life of 
the society and life of every individual. The three leaders were and are the only figures with authority to explain the ideology, one of them Kim Il Sung being its creator. The ideology was often compared to a state religion, especially under the leadership of Kim Jong Il (Lim, 2009). It plays equally important role under current leadership, however until now a little is known about specifics of Kim Jong Un's regime.

These two mentioned definitions of totalitarianism provide for a background to understand the ideational features of North Korean strategic culture. Myths, symbols, history and experiences are all subordinated to the values and principles of ruling ideology. History is specifically explained through a family history of family Kim, the ruling family with all their predecessor considered heroes of Korean nations (Martin, 2004). The most important and starting point of historical education in North Korea is period of Japanese colonization (started in 1905) when Korea lost its independence for the first time in its history. The generation of first leader is pictured as a successful guerrilla fighters that has brought the Japanese rule over Korean down (Lankov, 2007). What is the most interesting aspect of ideational sources of North Korean identity is, that the official ideology managed to incorporate some features of Korean culture imbedded in Confucianism. These are the filial piety, hierarchical composition of society, importance of fatherly figure impersonated by Kim Il Sung himself. However, the ideology has also rooted out some features of Korean political culture such as protests against oppression that had been part of Koreas history. Naturally, the education system is under full control of Korea's Workers Party and the main aim of the system is to teach people the thoughts and teachings of leaders.

What is important to mention related to ideology is that the main principle is focused on independence and self-reliance of the country in economy, in military affairs and in politics. This has and still is strongly influencing North Korean foreign and security policy. North Korean leadership and population carry a deep mistrust to foreign powers, it is rooted historically as the powers agreed to allow Japanese occupation of Korea at minimally two occasions, in 1905 when Treaty of Portsmouth has been singed and in 1918 at the Versailles Peace Conference (Buzo, 2003). During the Cold War it was reflected in the strategic balancing of North Korea between Chinese and Soviet influence, as the country has used their mutual disputes to its own benefits. After Cold War it was used in relations to the South Korea and the U.S. especially in those periods when talks were underway and significant amounts of aid were pouring into country. They were used for all purposes, including further development of nuclear and missile program. Additionally, there are two important features of the ideology added by second and third leader, the songun and byungjin principles respectively. The songun principle means military first policy under which everything was subordinated to the issues of military. This policy was introduced by Kim Jong Il and provided background for nuclear and missile program's development (Suh, 2002). In addition, Kim II, has ruled the country as a chairman of National Defence Commission that had controlled the army. The byungjin principle was introduced by Kim Jong Un and it means parallel development of economy and nuclear program (Cheon, 2013). Again in order to strengthen the independence and self-reliance of North Korea.

When we apply the material sources of strategic culture on North Korea we will have a complete picture of main motivations behind its foreign and security policy and we can conclude with some expectations for upcoming future. Looking at the geography of North Korea, or the whole Korean peninsula, it was always considered strategic as it is in the centre of the Northeast Asian region. The position has determined how 
the Korean people perceived themselves, as shrimps among sharks as Japan and China were their immediate neighbours. Korea and in particular North Korea was always sensitive to events that have happened in its surroundings. Mentioned Japanese occupation is a formative moment in its history, as the quest for survival and independence is strongly influenced by the experience from occupation (Buzo, 2003). The ever existing threat is emphasized by the official state propaganda. Even though after Korean war the U.S. has become the most serious enemy, Japan is on the second position. What we can say is, that North Korea is trying to find all possible tools to prevent to become victim of invasion again, since it was created.

As for resources North Korea has few natural resources as coal, iron ore and uranium. The first two mentioned are mainly exported to China, or were before the sanctions were imposed. The last is probably used for its indigenous nuclear program. North Korea is however depended on the import of crude oil especially from China, which was limited by the sanction regime as well. Concerning the climate North Korea often suffers by floods or periods of extreme drought. These are results of state planned agricultural policies of the past with a massive deforestation, artificial changes in river's flows, etc. The most seriously was the country affected in middle of 1990s when severe floods lead to low production of food and consequently to an unprecedented famine (Buzo, 2003). Due to the famine many of the party structures stopped working, which lead to a situation when the control of regime over the population has loosened. Therefore the military has been used to restore order and control and lay base for future songun policy.

Looking at the political structures we have already discussed the influence of ideology and emphasized the fact that North Korea is a totalitarian regime. Contrary to a traditional division of power known in democracies in DPRK the power is divided among military, party and leader with a leader having monopoly on decisions as he is a chairman of the party and commanderin-chief of armed forces. The decline of party's structures in the middle of 1990s has significantly influenced the character of Kim Jong Il's rule who relied on military. However in the process of leadership transition to the rule of Kim Jong Un party structures were renewed as the Koreas Worker's Party has an indoctrination monopoly and cult for future leader needed to be created (Park, 2010). Currently Kim Jong Un rules as a chairman of KWP, position he was elected at $7^{\text {th }}$ Party Congress that has taken place in 2016, almost 30 years after the $6^{\text {th }}$ Congress. This suggests a shift of regimes authority from army back to party, however military affairs still play an important role in DPRK as the nuclear development is part of the official party policy line, the mentioned byungjin (Kim, 2016). In this regard the institutions of defence as well as intelligence agencies are subordinated to the leader. What is known about North Korea is, beside its militarization a thorough surveillance of its own citizens and all visiting foreigners conducted by intelligence agencies.

As for the advancement of technology, this features is very important in North Korean strategic culture since its inception. The reason is rooted in historical experience mainly, as during the Korean War the U.S. army has considered to use atomic bombs against North Korea and parts of China. This moment is considered as a reason why DPRK started with its own nuclear program development (Buzo, 2003). Since the end of the Cold War the nuclear program has become an important feature of its foreign and security policy. Even more importance it gained with a new leader and increased number of nuclear test but also missile technology, especially in 2016 and 2017 when an unprecedented number of missiles with different range has been tested along with a hydrogen bomb. Regarding the nuclear and missile program, the rationale 
behind is the acquisition of tools of deterrence against any attack. North Korea operates with the strategy of nuclear deterrence as a Cold War proven reality of international relations. Regarding the nuclear program, since 2016 the DPRK has adopted its nuclear doctrine based on three principles: (1) DPRK will not be those from conflict parties to use nuclear weapons as first, (2) Commitment to contribute to prevention of nuclear proliferation, (3) Commitment to create a nuclear free world. At the same time the Congress's conclusion suggest that in a hostile external environment North Korea will aggressively develop its nuclear program as a tool for pressure and influence. The term nuclear diplomacy is used, suggesting that DPRK positions itself as a responsible nuclear power (Kim, 2016). Otherwise not many strategic documents are published by the regime.

Concerning the transnational norms, DPRK is a U.N. member state and a party to many agreements and declarations, however these seem not to be binding for the regime, as long as they do not bring some form of benefit. In general North Korea does not perceive international arena as cooperation-prone, to the contrary, international relations are considered as area of mistrust and self-help where everyone pursues own egoistic interests. With this approach also the norms are perceived by the leadership.

\section{What to expect from North Korea?}

Looking at the features of North Korean strategic culture, what does it say about how North Korea will behave in the upcoming future when two summits with U.S. and South Korean presidents are scheduled. Is the denuclearization really possible result of these talks? What we have seen since leader Kim Jong Un took power in late 2011 was a significant investment into further development of nuclear and missile program. Investment not only in sense of money but also political capital. Through the byungin principle the development of nuclear program has become an important pillar of Kim Jong Un's rule internally. Due to his young age he probably needed to persuade the population but mainly the older generation of ruling elite that he is able and capable of everything to protect country's existence. Externally, the perception of international relations has not changed, the uncertainty and unpredictability of behaviour of powers was only confirmed when D. Trump order attack on military base in Syria and when China started with rather thorough implementation of sanction regime. In this environment testing of new types of missiles with a range capable to reach the U.S. mainland is a rational decision to prevent any intervention. Besides, the nuclear deterrence is still a strong asset the North Korea is relaying on. North Korean leader has confirmed several times that the program was concluded and the DPRK has become a nuclear power and should be threated accordingly. It is therefore highly disputable that North Korea will be willing to denuclearize as the leader has confirmed several times within last month. However, he might be aware of the fact that denuclearization is rather long and complicated process and cannot be achieved within weeks or months. Additionally, there is no guarantee that the negotiation will last long enough to reach a final agreement. From North Korean perception of international relations and norms we can conclude that as long as they will bring benefits to the regime they will follow them.

If the North Korean regime truly continues in its former strategies, current diplomatic charm offensive is focused on receiving some benefits. In a certain way it was proved after the first ever Xi Jinping Kim Jong Un summit, when just 2 weeks after North Korean workers started to return to China after being expelled under sanction regime. The economic problems caused by the rather strict implementation of the sanctions are too severe for North Korea to preserve its assertive strategy from last two 
years. As the change of approach has worked in the past, and in addition the current South Korean administration was open for dialogue, Kim Jong Un used this opportunity and showed a positive attitude towards the negotiations.

\section{Conclusion}

To summarize, North Korea is a totalitarian regime with deep level of militarization, the people are prepared for conflict that can start at any time of their life. Naturally any shift to negotiations and diplomacy has positive impact on overall security situation, but North Korean strategic culture is more conflict and crisis oriented and therefore the diplomacy can bring only temporary de-escalation of crisis if North Korean demands will not be met.

\section{REFERENCES}

Bernholz, P. (2007) Ideology, sects, state and totalitarianism. In Maier, H., \& Schäfer, M. Totalitarianism and Political Religions, Volume II. Concepts for the comparison of dictatorship, 246-271. London: Routledge.

Buzo, A. (2003). Partyzánská dynastie. Politika a vedení Severní Koreje. Praha: BB Art

Cheon, S. (2013). The Kim Jong-un Regime's „Byungjin“ (Paralled Development) Policy of Economy and Nuclear Weapons and the 'April 1st Nuclearization Law', Korean Institute for National Unification Online Series CO 13-11, available at: http://www.kinu.or.kr/pyxis-api/1/digital-files/b150d4ac-0f1b-420a-b70d-18f3e0aa9972.

Howlett, D. (2005). Strategic culture: Reviewing recent literature. Strategic insights, Vol. 4, No. 1, available at: http://calhoun.nps.edu/bitstream/handle/10945/11212/howlett Oct05.pdf?sequence=1.

Kim, K. (2016). Analysis on the 7th congress of Korean Worker's Party(1): General Review, Korean Institute for National Unification Online Series CO 16-12, available at: http://www.kinu.or.kr/pyxis-api/1/digital-files/51df001d-b664-438d-8c5c-19db9d65bc30

Lankov, A. (2007). North of the DMZ: Essays on Daily Life in North Korea. Jefferson: McFarland \& Company.

Lantis, J. S. (2002). Strategic culture and national security policy. International studies review, Vol. 4, No. 3, 87-113.

Lim, J. (2009). Kim Jong Il's Leadership of North Korea. New York: Routledge.

Martin, B. K. (2004). Under the Loving Care of the Fatherly Leader. New York: Thomas Dunne Books.

Park, H. (2010). Kim Jong Il, the Military and the Party, and Kim Jong Un. Korean Institute of National Unification, available at: http://www.kinu.or.kr/www/jsp/prg/api/ $\underline{\text { dlVE.jsp}}$ ?menuIdx $=645 \&$ category $=72 \&$ thisPage $=19 \&$ searchField $=$ title\&searchText $=\&$ biblioI $\underline{\mathrm{d}=1447339}$.

Park, H. (2013). One Year into the '6.28 Policy Directives' - Content and Progress, Korean Institute for National Unification, Online Series CO 13-18, available at: http://www.kinu.or.kr/eng/pub/pub 05 01.jsp?page=1\&num=141\&mode=view\&field=\&text $=\&$ order $=\& \operatorname{dir}=\&$ bid $=$ EINGINSIGN\&ses $=$ \&category $=$.

Schäfer, M. (2004). Luigi Sturzo as a theorist of totalitarianism. In Maier, H., Totalitarianism and Political Religions, Volume I. Concepts for the comparison of dictatorship, 21-39. London: Routledge.

Suh, C. (2002). North Korea's „Military First“ Policy and Inter-Korean Relations. The Korean Journal of Defense Analysis, Vol. XIV, No. 2, 167-185.

Snyder, J. (1977). The Soviet strategic culture: Implications for limited nuclear operations. Santa Monica: Rand. 